IRA-International Journal of Education \&

Multidisciplinary Studies

ISSN 2455-2526; Vol.15, Issue 01 (April, 2019)

Pg. no. 24-31.

Institute of Research Advances

Institute of

http://research-advances.org/index.php/IJEMS

\title{
Effect of Parenting Styles on Student's Behaviour in Public Secondary Schools in Nairobi County-Kenya
}

Mercy Igoki Samuel $^{1 \#} \&$ Dinah Changwony ${ }^{2}$

${ }^{1,2}$ KAG EAST University, Kitengela, Kenya.

\# corresponding author.

Type of Work: Peer Reviewed

DOl: http://dx.doi.org/10.21013/jems.v15.n1.p3

How to cite this paper:

Samuel, M.I., Changwony, D. (2019). Effect of Parenting Styles on Student's Behaviour in Public Secondary Schools in Nairobi County-Kenya. IRA International Journal of Education and Multidisciplinary Studies (ISSN 2455-2526), 15(1), 24-31.doi: http://dx.doi.org/10.21013/jems.v15.n1.p3

(C) Institute of Research Advances.

This work is licensed under a Creative Commons Attribution-Non Commercial 4.0 International License subject to a proper citation to the publication source of the work.

Disclaimer: The scholarly papers as reviewed and published by the Institute of Research Advances (IRA) are the views and opinions of their respective authors and are not the views or opinions of the IRA. The IRA disclaims of any harm or loss caused due to the published content to any party.

Institute of Research Advances is an institutional publisher member of Publishers International Linking Association Inc. (PILA-CrossRef), USA. The institute is an institutional signatory to the Budapest Open Access Initiative, Hungary advocating the open access of scientific and scholarly knowledge. The Institute is a registered content provider under Open Access Initiative Protocol for Metadata Harvesting (OAl-PMH)

The journal is indexed \& included in WorldCat Discovery Service (USA), CrossRef Metadata Search (USA), WorldCat (USA), OCLC (USA), Open J-Gate (India), EZB (Germany) Scilit (Switzerland), Airiti (China), Bielefeld Academic Search Engine (BASE) of Bielefeld University, Germany, PKP Index of Simon Fraser University, Canada. 


\begin{abstract}
Parents form the core unit of a family and are at the very basic in the growth and development of their children. This includes moulding the children's behaviour at different stages of life. While studies have been conducted to establish what influence parenting styles have on their children, there is no consensus on how the behaviour of children is influenced by the method used by parents in bringing them up. This paper, therefore, is a result of a study that sought to establish the effect of parental styles on the behaviour of students in secondary schools in Nairobi County. Respondents were sampled from 60 public secondary schools in Nairobi County consisting of head-teachers, student counsellors and students who were targeted as respondents and from whom data was collected. The study established that students had been involved in indiscipline cases at least 1 to 3 times in the previous year. The study concludes that discipline and child behaviour will largely depend on the style of parenting adopted by the parents. While some parenting styles like authoritative promote good behaviour in children, others like authoritarian promote dysfunctional behaviours. Despite having money to pay for the students and facilitate their learning, the study found out that some parents did not spend time with their children hence increasing cases of indiscipline. The study recommends parents' involvement in promoting good behaviour among their children both at school and at home.
\end{abstract}

Keywords: Public secondary schools, Parenting style, Behaviour, Discipline, Nairobi County, Substance abuse

\title{
Introduction
}

The parenting styles used by parents in various homes influence children's disposition. This can either promote the children's development or be detrimental to their academic advancement. Effective teaching partly depends on students'level of discipline and discourages any factors that work against learning. However, the frequency and ferocity of unrest have adversely affected learning, injuring the operation and integrity of schools. According to Nakpodia[1], the increasing incidences of student unrest has eroded popular confidence in schools as institutions of learning. While many parents need assurance that learning will occur in a safe and wholesome environment that ensures the physical safety and psychological health of their children [1], a part of this achievement is their responsibility thus a concern that this paper addresses. The much pressure has forced teachers to divert their energies to dealing with indiscipline cases than focus on academics. As a result, school principals must become highly resourceful in coping with an increasingly turbulent learning environment, learn to anticipate cases of indiscipline, understand the external factors such as parenting styles that mould dysfunctional or delinquent behaviour of students [1] among other factors.

A study in New York, conducted by Dorner [2] revealed that if parents teach children to delay gratification, the latter would become accommodative, self-assertive and obedient to reasonable laws. However, if they fail to develop that sense of social competence in children, the latter would become socially alienated [2]. In exploring anti-normative behaviours during adolescence, studies have reported that over control by parents and restrictive interactions between parent and child have been associated with the following behaviour in adolescents: suicide, drug abuse, and male aggression [2, 3]. Similarly, Steinberg, Bomstein, and Vandell[4] observe that distant, hostile or conflicted family relationships as opposed to nurturing or supportive relationships are more likely to experience problems such as substance abuse.

Parenting styles, therefore, play a crucial role in helping or hindering certain educational processes. Clauss-Ehlers [5] observe that a child's upbringing is more important than the school environment in predicting scholastic performance. Therefore unravelling the role of parents in influencing student indiscipline is important. From the above studies, it is clear that how students behave in school does not depend so much on what is happening in the school but has a lot to do with their interaction with the parents and the kind of environment in which they have been brought up.

\section{Literature Underpinning}

Anderman, Winne, and Alexander [6] explain that there are four types of parenting approaches that profoundly influence the behaviour of adolescents. First, warm but controlling parents who restrict the behaviour of an adolescent will be protective or indulgent. Second, a cold or unemotional parent who is controlling towards the adolescent will be dictatorial and antagonistic. Third, a liberal or permissive parent who is highly nurturing will be 
democratic and co-operative. Fourth, a parent who is cold or hostile and permissive will be indifferent and detached from the child [6]. Understanding the factors that affect the discipline of a child is therefore important [7]. This paper addresses various parenting styles including authoritarian style, which is characterized by parents' having control, shaping and evaluating their children's attitudes and behaviour in accordance with a set of standards. The authoritarian parenting style entails aspects such as respect for authority, obedience, order preservation and work. In this form of parenting, the exchange between parents and children is not encouraged [8]. Atanda posits that the authoritarian style of parenting promotes low levels of child independence and lack of social responsibility describing it as formally being high in demand on the part of the parents and low in parental responsiveness to the child [8].

In another study Aremu[9] affirmed that the authoritarian style of parenting may lead to rejection of parents or society by children. The authoritarian parenting style is prohibitive in nature and compelling hence a high possibility of engendering fear, anxiety, and frustration among the children [9]. This will eventually negatively influence the behaviour of such children under the authoritarian parenting style. On the other hand, the authoritative style of parenting is characterised by and with an expectation of maturity in children's' behaviour. In this form of parenting, there are a clear set of standards by the parents and solid enforcement of standards and rules by use of sanctions and commands whenever necessary [10]. According to Baumrind, children from authoritative parenting families have proved to show maturity in behaviour, independence and responsibility aspects that positively motivates learning and academic achievement.

A study conducted in the United States of America recorded by Thomas, Leitch, Hughes, Midhigan and Dowell [3] showed that specific behavioural and personality traits in children or adolescents would emerge from the aforementioned parenting approaches. This implies that children who grow up in a family with hostile but controlling parents are likely to become withdrawn, neurotic, and quarrelsome [3]. In adolescence, these children are likely to become non-compliant and highly aggressive.

Ajowi and Simatwa[11] point out that the most common adolescent problem behaviours in Kenya are drug abuse, juvenile delinquency, alcohol abuse, truancy, school dropout, aggression, and rebellion. Moreover, Ajowi and Simatwa explain that aggression, drug abuse, and underage alcohol use are typical in student unrest [11]. Specific parenting traits play a role in child behaviour as concerns alcohol use, substance abuse, and aggression as discussed in this paper.

Koutakis[12] explains that considerable evidence connects an unfavourable home environment and underage alcohol use, chief of which are parents who take alcohol. He argues that parents who are distant, hostile, coercive, or authoritarian, would have adolescents with drinking problems. The perception of adolescents about their parents' parenting traits, therefore, influences their level of alcohol use [12].

Cleaver, Unell and Aldgate[13] argue that adolescents are more likely to use alcohol when it is easily accessible or if their parents seem to allow them to use alcohol. They add that regardless of the situation, the earlier an adolescent begins to use alcohol, the harder it will be for parents to intervene in the same [13]. Further, Cleaver Unell and Aldgateargue that adolescents who drink heavily often have parents with poor family management practices such as poor monitoring, unclear expectations implying that they scarcely reward positive behaviour and who sanctions or are indifferent to their children's alcohol use [13]. Therefore, parenting traits are decisive concerning the drinking habits of adolescents. More so, Cleaver Unell and Aldgate[13]and Knight, Roberts, Gabrielle, and Hook [14] argue that parental monitoring is crucial in reducing the probability of adolescents becoming involved in substance abuse. Likewise, poor parental-adolescent relationships are predictive of probable drug abuse by adolescents [15]. Adolescents with hostile or indifferent parents are more likely to abuse drugs. Stephens notes that better parentaladolescent relationships, noted by more monitoring and more supportive relationships, can help adolescents overcome even peer pressure on drug use [15].

Knight et al.[14] explain that aggression; adolescents with authoritarian parents would be especially aggressive and unruly in the school setting. Parents who use excessive physical punishment or who are overly protective or overly demanding would have aggressive adolescents [14]. However, those who fail to limit the amount of aggression that their children display at home, encouraging their children to become aggressive outside the home environment such as, inciting them to fight for their rights, would also have more aggressive children[14]. Okumu[16] adds that highly aggressive adolescents are susceptible to participating in student unrest because they lack the moral and rational 
abilities to deal with interpersonal conflicts through dialogue and social responsibility. Instead, they believe that violence is a legitimate mechanism for resolving conflict [16].

Okumualsopoints out that developmental literature suggests that adolescents live in fluid social systems, explaining that changing or modifying parenting traits and altering unfavourable school settings can be central to any therapeutic interventions to the problem of student indiscipline behaviour [16]. Therefore, demonstrating the role of parenting traits in such behaviour would enable intelligent interventions. Cross-cultural studies have demonstrated that parenting traits are basic to problem behaviour in adolescents [17, 18].

\section{Methodology}

The study upon which this paper is drawn was conducted in Nairobi County with the authors' aim to establish the effect of parenting styles on the behaviour of secondary school going students, in public schools. The research design providing a detailed outline of how the investigation was conducted as described byCreswell[19] was descriptive in nature. The descriptive research design was therefore concerned with describing the characteristics of a group of individuals [20] in this case secondary school students. Gratton and Jone [21] argue that descriptive designs focus on the current status of occurrences rather than the causes of the current occurrences. The research design, therefore, enabled the description of the effect of parenting style on student discipline in public secondary schools in Nairobi County providing a layout on the effects of parenting style on student behaviour.

The target population comprised head-teachers, guidance and counselling teachers and students in 60 schools in public secondary schools in Nairobi County-Kenya with an average of one head-teacher, one guidance and a counselling officer from each school. The study also targeted 1200 students. The distribution of the target population is presented in Table 1.

\section{Table 1. Target}

\begin{tabular}{l|l} 
& \\
Population Category & Target Population \\
\hline Head-teachers & 60 \\
Teacher counsellors & 60 \\
Students & 1200 \\
Total & $\mathbf{1 3 2 0}$ \\
\hline
\end{tabular}

A sample size of 132 respondents was then obtained from the target population resulting in only six schools that participated in the study. This included 20 students from each of the six schools under study, one guidance and counselling teacher, and one head-teacher(s) from each of the schools. This was obtained through stratified random sampling.

Table2. Sample size

\begin{tabular}{l|l|l|l} 
Respondent Category & $\begin{array}{l}\text { Total Number of } \\
\text { schools }\end{array}$ & $\begin{array}{l}\text { No of students } \\
\text { sampled }\end{array}$ & Sample of schools \\
\hline Boys Boarding & 07 & 20 & 1 \\
Girls Boarding & 10 & 20 & 1 \\
Boys Day & 08 & 20 & 1 \\
Girls Day & 05 & 20 & 1 \\
Mixed Day & 24 & 20 & 2 \\
Mixed boarding & 06 & 0 & 0 \\
Total Schools & $\mathbf{6 0}$ & $\mathbf{1 2 0}$ & $\mathbf{0 6}$ \\
\hline
\end{tabular}

Data collection was done using questionnaires after conducting a pilot study in order to ascertain the usability of the tools. The collected data were coded according to similar responses and analysed using Statistical Package of Social Sciences (SPSS) to determine the following family processes: parental monitoring, parental discipline methods, and parental demands to the respondents' use of alcohol, drugs, drop-out, disobedience, alcohol, absenteeism and theft. Frequencies, percentages, mean and standard deviation were worked out for descriptive data. 


\section{Results and Discussion}

The study targeted a sample of 132 respondents and obtained a $100 \%$ response rate. The aim of the study was to establish the effect of parenting style on the students' behaviour in secondary schools in Nairobi County. The authors in addressing this, therefore considered various aspects including students' involvement in indiscipline cases for the year 2012, the number of times students had gotten involved in indiscipline in one year, the number of indiscipline cases dealt with in a week by the head teachers, indiscipline cases in order of frequency and students' agreement level with statements on indiscipline.

Table 3. Students' involvement in indiscipline 2012

\begin{tabular}{lll}
\hline Involvement in indiscipline & Frequency & Percentage \\
\hline True & 70 & 58 \\
False & 50 & 42 \\
\hline Total & $\mathbf{1 2 0}$ & $\mathbf{1 0 0 . 0 0}$ \\
\hline
\end{tabular}

Table 4 shows if the students had been involved in indiscipline for the last one year. From the findings, 58\% of the students had been involved in indiscipline for the last one year while $42 \%$ of the students had not been involved in indiscipline for the last year at the time of the study.

Table 5. Students' involvement in indiscipline 1 to 3 times in the last one year

\begin{tabular}{lll} 
Involvement in indiscipline & Frequency & Percentage \\
\hline True & 40 & 33 \\
False & 30 & 25 \\
N/A & 50 & 42 \\
\hline Total & $\mathbf{1 2 0}$ & $\mathbf{1 0 0 . 0 0}$ \\
\hline
\end{tabular}

As shown in Table 5, it was found out that $33 \%$ of the students had been involved in indiscipline cases at least 1 to 3 times in the previous one year, $25 \%$ of them had not been involved in indiscipline 1 to 3 times for the last one year.

Table 6.Students'involvement in indiscipline more than 3 times in one year

\begin{tabular}{lll}
\hline Involvement in indiscipline & Frequency & Percentage \\
\hline True & 30 & 25 \\
False & 40 & 33 \\
N/A & 50 & 42 \\
\hline Total & $\mathbf{1 2 0}$ & $\mathbf{1 0 0}$ \\
\hline
\end{tabular}

Table 6 displays information on whether students had been involved in indiscipline 4 or more times in one year. From the findings, $33 \%$ of the students had not been involved in indiscipline cases 4 or more times while $25 \%$ of the students had been involved in indiscipline 4 times or more in one year.

Table 7. Number of indiscipline cases dealt within a week by head teachers

\begin{tabular}{lll}
\hline Involvement in indiscipline & Frequency & Percentage \\
\hline 1 to 2 & 2 & 33 \\
3 to 4 & 3 & 50 \\
5 and more & 1 & 17 \\
\hline Total & $\mathbf{6}$ & $\mathbf{1 0 0}$ \\
\hline
\end{tabular}


Further, the study sought to establish the number of indiscipline cases the head teacher dealt within a week andthe findings are shown in Table 7 . According to the findings, 50\% of the head teachers dealt with 3 to 4 indiscipline cases in a week,33\% of the head teachers dealt with1 to 2 indiscipline cases in a week and $17 \%$ of the head teachers dealt with5 and more indiscipline cases in a week.

Table 8. Indiscipline cases in order of frequency

\begin{tabular}{lll}
\hline Indiscipline Cases & Mean & $\begin{array}{l}\text { Standard } \\
\text { Deviation }\end{array}$ \\
\hline School drop out & 2.481 & 0.15 \\
Drug abuse & 3.942 & 0.14 \\
Use of vulgar language & 4.741 & 0.36 \\
Disobedience & 4.832 & 0.69 \\
Theft & 4.484 & 0.45 \\
Truancy & 3.805 & 0.14 \\
Lateness & 4.492 & 0.10 \\
Dishonesty & 4.903 & 0.14 \\
Smoking & 3.396 & 0.19 \\
Alcoholism & 3.706 & 0.38 \\
\hline
\end{tabular}

Table 8 indicates findings on the indiscipline cases in their order of frequency. From the findings, dishonesty, disobedience and use of vulgar language were very frequent in occurrence. This is depicted by mean of $4.903,4.832$ and 4.741 respectively. In addition, lateness, theft, drug abuse, truancy and alcoholism occurred frequently as shown by mean of 4.492, 4.484, 3.942, 3.805 and 3.706 respectively. Moreover, smoking occurred somehow frequently as shown by a mean of 3.396. The item that showed fewer occurrences was school dropout as shown by a mean of 2.481 .

Table 9. Students' agreement level with statements on indiscipline

\begin{tabular}{lll}
\hline Students agreement & Mean & $\begin{array}{l}\text { Standard } \\
\text { deviation }\end{array}$ \\
\hline I spend at least 2 hours with one of my parents/guardian every day while at & & \\
home. & 2.378 & 1.15 \\
My parents/guardian have very high expectations of me & 4.682 & 1.14 \\
My parents/guardian allow me to make my own decisions & 3.465 & 0.96 \\
My parents/guardian appreciate me & 3.391 & 1.09 \\
My parents/guardian respond immediately to my requests & 2.904 & 1.05 \\
My parents/guardian notice and reward good behaviour & 2.863 & 1.14 \\
My parents/guardian punish bad behaviour immediately & 3.602 & 1.10 \\
My parents/guardian give me responsibilities to do at home & 3.271 & 1.14 \\
My school fee is always paid before or on the 1st day of every new term & 3.981 & 1.20 \\
My parents pay for co-curricular activities at school & 4.183 & 1.06 \\
One of my parents/guardian is a manager at workplace & 3.869 & 1.19 \\
At least one of my parents/guardian does not work over the weekend & 2.174 & 1.19 \\
At least one of my parents/guardian attends all school functions & 3.503 & 1.08 \\
At least one of my parents/guardian always sleep at home after a job every day & 3.91 & 1.17 \\
My family attends Church/ mosque/ temple every week & 3.761 & 0.50 \\
My family prays together every day & 1.942 & 0.72 \\
\hline
\end{tabular}


According to Table 9, the students strongly agreed that parents/guardians have very high expectations of them as shown by a mean of 4.682. Also, the students agreed that parents pay for co-curricular activities at school, school fees are always paid for before or on the first day of every new term, at least one of the parents/guardian always sleep at home after a job every day and one of the parents/guardian is a manager at workplace as shown by a mean of 4.183, 3.981, 3.91 and 3.869 respectively. In addition, the students agreed thatthe family attends Church/mosque/temple every week, parents/guardian punish bad behaviour immediately and at least one of the parents/guardian attends all school functions as shown by a mean of 3.761, 3.602 and 3.503 respectively.

Moreover, the students agreed that parents/guardian allow them to make their own decisions, parents/guardian appreciate students, parents/guardian give their children responsibilities to do at home, parents/guardian respond immediately to the requests and parents/guardian notice and reward good behaviour as shown by mean of 3.465, $3.391,3.271,2.904$ and 2.863 respectively. In addition, the students agreed that they spend at least 2 hours with one of the parents/guardians every day while at home, at least one of the parents/guardian does not work over the weekend and the family prays together every day as shown by a mean of 2.378, 2.174 and 1.942 respectively.

\section{Conclusion}

The study concludes that discipline will largely depend on the style of parenting adopted by the parents. While some parenting styles promote good behaviour in children, like the authoritative style other parenting styles like the authoritarian promote dysfunctional behaviours in secondary school students. Parents may contribute much emotional support but exhibit little control. There were many indiscipline cases in schools some of which include dishonesty, disobedience and use of vulgar language. Others included lateness, theft, drug abuse, truancy, alcoholism and school dropout which was rare in the sampled schools.

The study also concludes that parents/guardian had very high expectations of their children thus increasing indiscipline. Parents have money to pay for the students though they did not spend time with them a factor that led to increased student indiscipline. Parents/guardian allow students to make their own decisions, parents/guardian appreciate students. Parents/guardian gives students responsibilities to do at home. Parents/guardian did not notice and reward good behaviour.

\section{Recommendations}

The study recommends students to be disciplined both at school and at home and that parents and teachers punish indiscipline students immediately. The study recommends parents/guardian not to have unreasonably very high expectations of students.

\section{References}

[1]. Nakpodia, P.D. (2010). Teachers' disciplinary approaches to students' discipline problems in Nigerian secondary schools. Abraka, Nigeria: Department of Education Administration and Policy Studies.

[2]. Dorner, J. (2006). A self-measure of personality growth: Self-concept maturity (SCM), development, validation and age effect. (A doctoral dissertation). Jacobs University. Fromhttp://www.jacobsUniversity.de/phd/files/1149071132.pdf.onJanuary 7,2013

[3]. Thomas, D., Leitch, C., Hughes, C., Midhigan, A., \& Dowell, K. (2009).Emerging Practices in the prevention of child abuse and neglect. United States of America: Department of Health and Human Services.

[4]. Steinberg, L. D., Bomstein, M. H., \&Vandell, D. L. (2010).Lifespan development: Infancy through adulthood. Mason, Ohio: Cengage Learning.

[5]. Clauss-Ehlers, C. (ed.). (2010). Encyclopaedia of cross-cultural school psychology. New Jersey: Springer.

[6]. Anderman, E., Winne, P. H., \& Alexander, A. (2012). Handbook of of educational Psychology. New York: Routledge.

[7]. Benson, J. P. \& Haith, M. M. (2010).Social and emotional development: In infancy and early childhood development. San Diego, California: Elsevier, Inc.

[8]. Atanda, A. I. (2013). Parenting style and students academic achievement in junior secondary schools in Ogun State, Nigeria. Journal of Emerging Trends in Educational Research and Policy Studies5(1), 20-24.

[9]. Aremu, A. O. (2001). Academic performance 5-factor inventory. Ibadan: Stirling-Horden Publishers

[10]. Baumrind, D. (2016). Parenting styles \& theory. Lesson manuscript

[11]. Ajowi, J. O., \&Simatwa, E. W. M. (2010).The role of guidance and counselling in promoting student discipline in secondary schools in Kenya: A case study ofKisumudistrict. Educational Research and Review, 5(5), 263-272. 
[12]. Koutakis, N. (2011).Preventing underage drinking alcohol through working with parents.Ineko: Orebro University Publication.

[13]. Cleaver, H., Unell, I., \&Aldgate, J. (2011). Children need parenting capacity: child abuse, Parental mental illness, learning disability, substance abuse, and domestic violence ( $\left.2^{\text {nd }} \mathrm{ed}.\right)$. London: Publishing Information Solution Ltd.

[14]. Knight, J., Roberts, T., Gabrielle, J., \& Hook, S. (2009). Informing preventive services: A British futures handbook. United Kingdom: Routledge.

[15]. Stephens, F. J. (2011).Mormon parenting secrets: Time-tested methods for raising exceptional children. United States of America: Mormon Parenting Institute Publication.

[16]. Okumu, A. (2011). Introduction to guidance and counselling. Nairobi: African Virtual University Publication.

[17]. Hayes, L., Smart, D., Toumbourou, J. W., \&Sanaon, R. (2004). Parenting influences on adolescent alcohol use. Australia: Australian Institute of Family Studies Publication.

[18]. Wijsbroek, S. A. M., Raaijmakers, W. W., Hale, Q. A. W., \&Meeus, W. H. J. (2011). The direction of effects between perceived parental behavioural control and psychological control of adolescents self-reported GADs and SADs. European child and Adolescent Psychiatry Journal, 20(7), 361-371.

[19]. Creswell, J. W. (2013). Quantitative and mixed methods approach ( $3^{\text {rd }}$ Ed).Thousand Oaks: SAGE Publications, Inc.

[20]. Kothari, C. R. (2008).Research Methodology: Methods and techniques (2 ${ }^{\text {nd }}$ ed.). New Delhi: New international Publishing Limited.

[21]. Gratton, I., \& Jones, C. (2010). Research methods for sports studies (2 ${ }^{\text {nd }}$ ed.). New York: Taylor and Francis Publications. 